\title{
USE OF SAWDUST Eucalyptus sp. IN THE PREPARATION OF ACTIVATEDCARBONS
}

\section{Utilização de serragem de Eucalyptus sp. na preparação de carvões ativados}

\author{
Gabriela Martucci Couto ${ }^{1}$, Anelise Lima de Abreu Dessimoni², \\ Maria Lúcia Bianchi ${ }^{3}$, Deise Morone Perígolo ${ }^{3}$, Paulo Fernando Trugilho ${ }^{4}$
}

\begin{abstract}
Wood sawdust is a solid residue, generated in the timber industry, which is of no profitable use and can cause serious environmental problems if disposed inadequately. The aim of this study was to use the eucalyptus sawdust in the preparation of activated carbons $\mathrm{AC}$ ) and test them as adsorbents of methylene blue (MB) and phenol, representative pollutants from aqueous effluents of various industries. The eucalyptus sawdust was characterized by instrumental analysis such as elementary analysis (CHNS-O), thermogravimetric analysis (TGA), infrared spectroscopy (FTIR) and scanning electron microscopy (SEM). The activated carbons were prepared by physical activation with carbon dioxide $\mathrm{AC}_{-} \mathrm{CO}_{2},\left(10^{\circ} \mathrm{C} \mathrm{min}^{-1}, 850^{\circ} \mathrm{C}, 1 \mathrm{~h}\right)$ and by chemical activation with potassium carbonate $\mathrm{AC}_{-} \mathrm{K}_{2} \mathrm{CO}_{3}\left(10^{\circ} \mathrm{C} \mathrm{min}^{-1}, 850^{\circ} \mathrm{C}, 3 \mathrm{~h}\right)$. The $\mathrm{AC}_{-} \mathrm{CO}_{2}$ and $\mathrm{AC} \_\mathrm{K}_{2} \mathrm{CO}_{3}$ were characterized by CHN-O, TGA, FTIR, $\mathrm{N}_{2}$ adsorption/desorption (BET) to evaluate the specific surface area and SEM. The resulting activated carbons were tested for their ability to adsorb MB and phenol in water. The activated carbons produced in this work were predominantly microporous and showed specific surface area of about $535 \mathrm{~m}^{2} \mathrm{~g}^{-1}$. The $\mathrm{AC}_{-} \mathrm{K}_{2} \mathrm{CO}_{3}$ was more effective in the adsorption of $\mathrm{MB}\left(81 \mathrm{mg} \mathrm{g}^{-1}\right)$ and phenol $\left(330 \mathrm{mg} \mathrm{g}^{-1}\right)$ than $\mathrm{AC}_{-} \mathrm{CO}_{2}\left(32 \mathrm{mg} \mathrm{g}^{-1}\right.$ and $172 \mathrm{mg} \mathrm{g}^{-1}$, respectively, for MB and phenol).
\end{abstract}

Index terms: Agro-industrial residues, adsorbents, pollutants.

\section{RESUMO}

A serragem é um resíduo sólido, gerado na indústria madeireira, que não tem uso rentável e pode causar sérios problemas ambientais quando disposta inadequadamente. Neste estudo, objetivou-se utilizar a serragem de eucalipto na preparação de carvões ativados (AC) e testá-los como adsorventes do corante azul de metileno (MB) e fenol; moléculas que representam poluentes de efluentes industriais. A serragem de eucalipto foi caracterizada por análises instrumentais, tais como: análise elementar (CHNS-O), análise termogravimétrica (TGA), espectroscopia na região do infravermelho (FTIR) e microscopia eletrônica de varredura (SEM). Os carvões ativados foram preparados por ativação física com dióxido de carbono $\mathrm{AC} \mathrm{CO}_{2},\left(10^{\circ} \mathrm{Cmin}^{-1}, 850^{\circ} \mathrm{C}, 1 \mathrm{~h}\right)$ e pela ativação química com carbonato de potássio- $\mathrm{AC}_{-} \mathrm{K}_{2} \mathrm{CO}_{3}\left(10^{\circ} \mathrm{Cmin}^{-1}, 850^{\circ} \mathrm{C}, 3 \mathrm{~h}\right)$. O AC_CO e AC_K $\mathrm{CO}_{3}$ foram caracterizados por CHNO, TGA, FTIR, adsorção/dessorção de $\mathrm{N}_{2}$ (área BET) para avaliar a área superficial específica e SEM. Os carvões ativados resultantes foram testados quanto à capacidade de adsorver MB e fenol na água. Os carvões produzidos apresentaram características de material microporoso, apresentando área superficial média de cerca de $535 \mathrm{~m}^{2} \mathrm{~g}^{-1}$. O AC_K $\mathrm{K}_{2} \mathrm{CO}_{3}$ foi mais eficiente na adsorção do $\mathrm{MB}\left(81 \mathrm{mgg}^{-1}\right)$ e fenol (330 $\left.\mathrm{mgg}^{-1}\right)$ que o AC_CO $2\left(32 \mathrm{mg} \mathrm{g}^{-1}\right.$ e $172 \mathrm{mg} \mathrm{g}^{-1}$, respectivamente, para MB e fenol).

Termos para indexação: Resíduos agroindustriais, adsorventes, poluentes.

(Received in june 13, 2011 and approved in december 26, 2011)

\section{INTRODUCTION}

In Brazil, a land with a large reforested area, many eucalyptus species are widely planted because they are important suppliers of raw material for various industrial purposes (SILVEIRA et al., 2004; TRUGILHO, 2009; CUSTÓDIO; BARBIN, 2009; DOMINGUES et al., 2010).

The reuse of waste biomass is becoming an issue of ever growing importance, not only for economic reasons but also for environmental ones (MARTINS et al., 2007).

Biomass, mainly derived from agricultural solid waste, is a preferable option for activated carbon (AC) precursors (GONÇALVES et al., 2007). Those materials are cheap, renewable and abundantly available (DIN et al., 2009). Thus, one of the possibilities of using such waste is in the manufacture of ACs, which are a well-known materials used in an increasing number of environmental applications like water and wastewater treatment, gas filters, and so forth. (POLLARD et al., 1992; DIAS et al., 2007).

ACs have a very complex pore structure, large surface area, good catalytic activity and chemical stability, and a variety of oxygen-containing functional groups on

1Universidade Federal Rural de Pernambuco/UFRP - Departamento de Ciência Florestal - Recife - PE - Brasil

2Universidade Federal de Lavras/UFLA-Departamento de Química/DQI - Cx. P. 3037-37200-000 - Lavras - MG - Brasil - aaaneliselima@hotmail.com.br 3Universidade Federal de Lavras/UFLA - Departamento de Química/DQI - Lavras - MG - Brasil

${ }^{4}$ Universidade Federal de Lavras/UFLA - Departamento de Ciências Florestais/DCF - Lavras - MG - Brasil

Ciênc. agrotec., Lavras, v. 36, n. 1, p. 69-77, jan./fev., 2012 
the surface (JUAN; KE-QIANG, 2009). The characteristics of ACs depend on the activation methods as well as on the properties of the starting materials. There are two activation methods in the production of activated carbons: physical (or thermal) and chemical (MARSH; RODRÍGUEZREINOSO, 2006). The physical activation method involves carbonization of the raw material and the subsequent activation at high temperature in a carbon dioxide atmosphere or with steam. The chemical activation method involves the carbonization of the raw material previously impregnated with a chemical agent such as zinc chloride, phosphoric acid, potassium hydroxide or others (DUMAN et al., 2009).

ACs have demonstrated themselves to be highly efficient for the removal of many compounds such as dyes, metal ions, and low molar mass organic compounds (GONÇALVES et al., 2007; OLIVEIRAel at., 2009; DURAL et al., 2011; MAHMOODI et al., 2011; NIETO-DELGADO et al., 2011).

Methylene blue (MB) which is the most commonly used substance for dying cotton, wood and silk can cause some harmful effects. Therefore, the removal of such dye from waste streams before discharge to public water sources is of primary concern (DENG et al., 2009).

Phenol is frequently derived from petrochemicals, plastics, paints, pharmaceutical and steel industries (CANIZARES et al., 2006). Excessive presence of phenol and its derivatives in natural water is considered as a serious threat to human health and overall water quality (BHATNAGAR, 2007). The discharge of industrial wastes (generated in chemical industry activities) and the leaching from agricultural and forest land (when the application of chemical fertilizers and pesticides is made) are the main sources of organic pollution in several water streams (DIAS et al., 2007). Phenolic compounds are very harmful to organisms even at low concentrations due to their toxicity and carcinogenic properties. Thus, it is recommended to fully remove the phenol from industrial effluents before entering the water stream (OZKAYA, 2006).

In this article, the preparation and characterization of activated carbons from eucalyptus sawdust were reported and the adsorption equilibrium of methylene blue and phenol on those ACs were evaluated.

\section{MATERIAL AND METHODS}

\section{Preparation of the activated carbons}

Eucalyptus sp. sawdust samples, used as a carbonaceous precursor for the production of activated carbons, were donated by a sawmill in the city of Lavras, Brazil. The sawdust was dried at $80^{\circ} \mathrm{C}$ for 6 hours, sieved into a uniform size $(25 \mathrm{~mm})$ and stored at room temperature.

Two methods of activation were used to prepare the ACs: physical activation with $\mathrm{CO}_{2}\left(\mathrm{AC}_{-} \mathrm{CO}_{2}\right)$ and chemical activation with $\mathrm{K}_{2} \mathrm{CO}_{3}\left(\mathrm{AC}_{-} \mathrm{K}_{2} \mathrm{CO}_{3}\right)$.

To produce the $\mathrm{AC} \mathrm{K}_{2} \mathrm{CO}_{3}$, the eucalyptus sawdust was impregnated $\left(1 \mathrm{~g} \mathrm{~g}^{-1} \mathrm{~K}_{2} \mathrm{CO}_{3}\right)$ with $\mathrm{K}_{2} \mathrm{CO}_{3}$ using $100 \mathrm{~mL}$ of distilled water, $8 \mathrm{~g}$ of the eucalyptus sawdust and $8 \mathrm{~g}$ of $\mathrm{K}_{2} \mathrm{CO}_{3}$. The mixture was heated at $80^{\circ} \mathrm{C}$ under stirring until complete drying and put in an oven at $110^{\circ} \mathrm{C}$ for $24 \mathrm{~h}$. Then, the material was placed in a tubular furnace and heated at a rate of $10^{\circ} \mathrm{C} \mathrm{m^{-1 }}$ until $500^{\circ} \mathrm{C}$ and held at this temperature for $3 \mathrm{~h}$. The resulting material was washed to remove the remaining chemical agent and dried for $24 \mathrm{~h}$ at $80^{\circ} \mathrm{C}$.

In the physical activation (to produce $\mathrm{AC}_{-} \mathrm{CO}_{2}$ ), 10 $\mathrm{g}$ of the eucalyptus sawdust was previously pirolysed in a tubular furnace at $500^{\circ} \mathrm{C}$ for $3 \mathrm{~h}$ (heating rate of $10^{\circ} \mathrm{C} \mathrm{min}^{-1}$ )

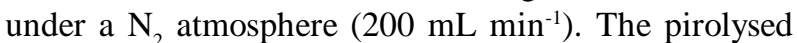
material was activated using a $150 \mathrm{~mL} \mathrm{~min}^{-1} \mathrm{CO}_{2}$ flow at $850^{\circ} \mathrm{C}$ (heating rate of $10^{\circ} \mathrm{C} \mathrm{min}^{-1}$ ) for $1 \mathrm{~h}$.

\section{Characterization of the activated carbons}

The surface area and pore size distribution of the materials was obtained by means of $\mathrm{N}_{2}$ adsorption/ desorption isotherms at $77 \mathrm{~K}$ in an Autosorb-1, Quantachrome. The specific surface area was calculated by the BET method and the pore size distribution was calculated by DFT.

Surface morphology of the produced activated carbons was investigated using scanning electron microscopy (SEM). The samples were prepared in stub holders with double face carbon tape, placed on an aluminum sheet and covered with gold, using a Balzers SCD 050 evaporator.

Analyses of CHN-O of $\mathrm{AC}_{-} \mathrm{K}_{2} \mathrm{CO}_{3}, \mathrm{AC}_{-} \mathrm{CO}_{2}$ and of eucalyptus sawdust were obtained using a Thermo equipment, Flash EA 1112 series.

The thermogravimetric analysis of the materials was performed in a Shimadzu DTG-60AH. For the analyses, approximately $10 \mathrm{mg}$ of each sample were heated at $10^{\circ} \mathrm{C}$ $\min ^{-1}$ from 25 to $900^{\circ} \mathrm{C}$ under $\mathrm{N}_{2}$ flow.

The functional groups on the AC samples were analyzed by Fourier Transform Infrared (FTIR) spectroscopy. All spectra were collected on a Digilab Excalibur, FTS 3000 series, operating in the infrared region of $400-4000 \mathrm{~cm}^{-1}$ with a $8 \mathrm{~cm}^{-1}$ resolution. The samples were prepared as $\mathrm{KBr}$ tablets. 


\section{Adsorption tests}

The adsorption tests were conducted using solutions of methylene blue dye and phenol, whose molecular structures are shown in Figure 1.

Adsorption isotherms were obtained using $10 \mathrm{mg}$ of adsorbent materials in contact with $10 \mathrm{~mL}$ of solutions with different concentrations $(25,50,100,200,500$ and 1000 $\mathrm{mg} \mathrm{L}^{-1}$ ) of adsorbate (methylene blue or phenol). The solutions were kept under stirring for 24 hours at room temperature $\left(25 \pm 2^{\circ} \mathrm{C}\right)$.

The determination of the equilibrium concentration was made by UV-visible spectroscopy (Shimadzu-UV-1601 $\mathrm{PC})$ for methylene blue $(\mathrm{l}=665 \mathrm{~nm})$ and phenol $(\mathrm{l}=270 \mathrm{~nm})$.

The isotherms were evaluated using the Langmuir and Freundlich models.

\section{RESULTS AND DISCUSSION}

\section{Characterization of the activated carbons}

Figure 2 presents the $\mathrm{N}_{2}$ adsorption/dessorption isotherms at $77 \mathrm{~K}$ of $\mathrm{AC} \_\mathrm{CO}_{2}$ and $\mathrm{AC} \_\mathrm{K}_{2} \mathrm{CO}_{3}$.<smiles></smiles>

(a)
The area obtained for the AC was 528 and $539 \mathrm{~m}^{2} \mathrm{~g}^{-1}$ for AC_CO $\mathrm{CO}_{2}$ and $\mathrm{AC}_{-} \mathrm{K}_{2} \mathrm{CO}_{3}$, respectively. According to Suhas and Ribeiro Carrot (2007) activated carbon may have surface areas ranging from 500 to $2000 \mathrm{~m}^{2} \mathrm{~g}^{-1}$, showing that the surface area found for $\mathrm{AC}_{-} \mathrm{CO}_{2}$ and $\mathrm{AC}_{-} \mathrm{K}_{2} \mathrm{CO}_{3}$ is characteristic of a porous material. In terms of surface areas, those differences are not significant; however, the carbons were activated in different ways, so they have different surface chemical groups. As the carbons have different surface chemistry, even with values of surface areas so close, they have different behaviors depending on the adsorbate used (MB or phenol).

The isotherm exhibits high $\mathrm{N}_{2}$ adsorption at low pressures, indicating predominantly microporous $\mathrm{AC}$. We can also observe a very small variation in the amount of adsorbed $\mathrm{N}_{2}$ with increasing pressure $\left(\mathrm{p} / \mathrm{p}_{0}\right)$, which is typical for microporous materials. Figure 3 confirms the microporosity of AC_CO $\mathrm{CO}_{2}$ and $\mathrm{AC} \mathrm{K}_{2} \mathrm{CO}_{3}$, since most of the pores are smaller than $20 \AA$.

The micrographs of the precursor material (eucalyptus sawdust) and of activated carbons $\mathrm{AC}_{-} \mathrm{CO}_{2}$, AC_ $\mathrm{K}_{2} \mathrm{CO}_{3}$ are shown in Figure 4.<smiles>Oc1ccccc1</smiles>

(b)

Figure 1 - Chemical structures of methylene blue (a) and phenol (b).
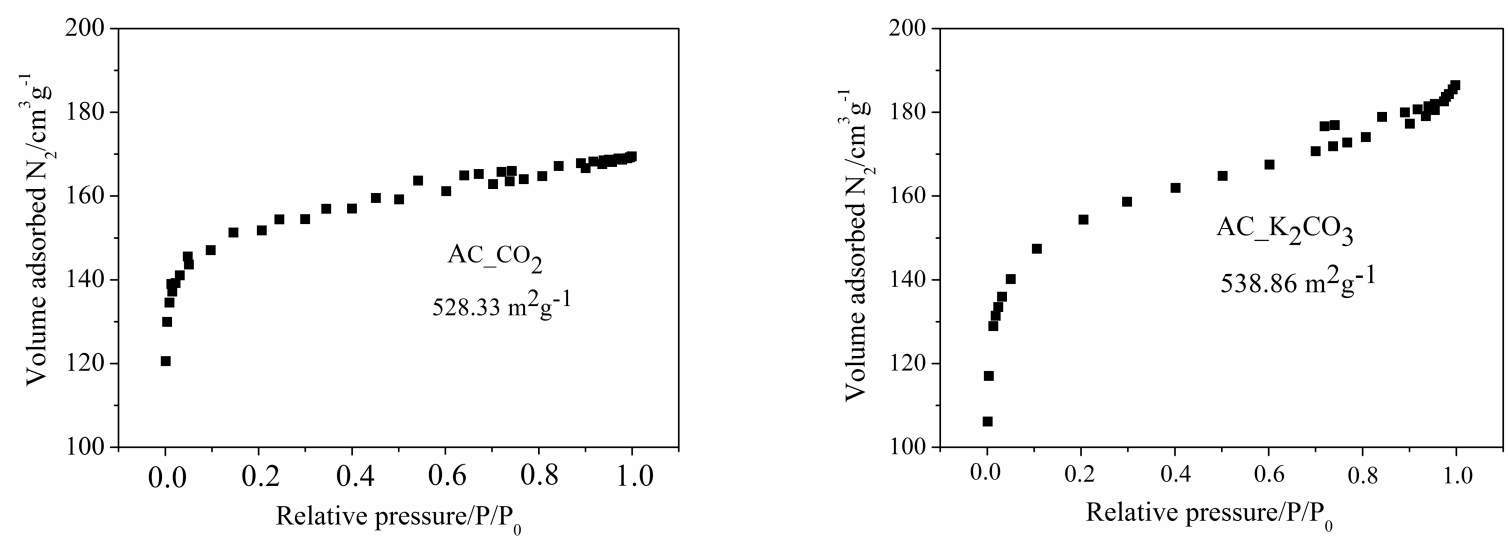

Figure $2-\mathrm{N}_{2}$ adsorption/desorption isotherms at $77 \mathrm{~K}$, for $\mathrm{AC} \_\mathrm{CO}_{2}$ and $\mathrm{AC} \_\mathrm{K}_{2} \mathrm{CO}_{3}$. 
It is observed that the morphology of the precursor material changed after the pyrolysis and activation process, forming a structure with larger pores which can be attributed to the decomposition of labil compounds during the process.

The carbon, hydrogen, nitrogen and oxygen contents found in the sawdust and in the activated carbons by means of elemental analysis are presented in Table 1.

Comparing the ACs with the sawdust, it is observed that the carbon content increases and the levels of

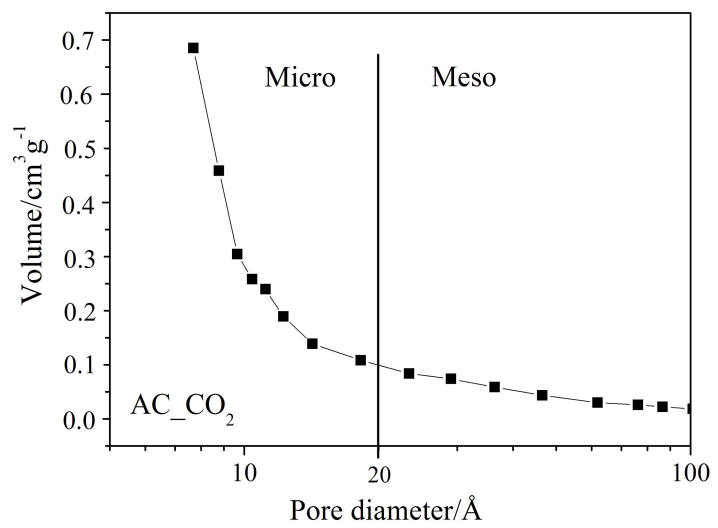

Figure 3 - Pores size distribution of $\mathrm{AC}_{-} \mathrm{CO}_{2}$ and $\mathrm{AC} \_\mathrm{K}_{2} \mathrm{CO}_{3}$.

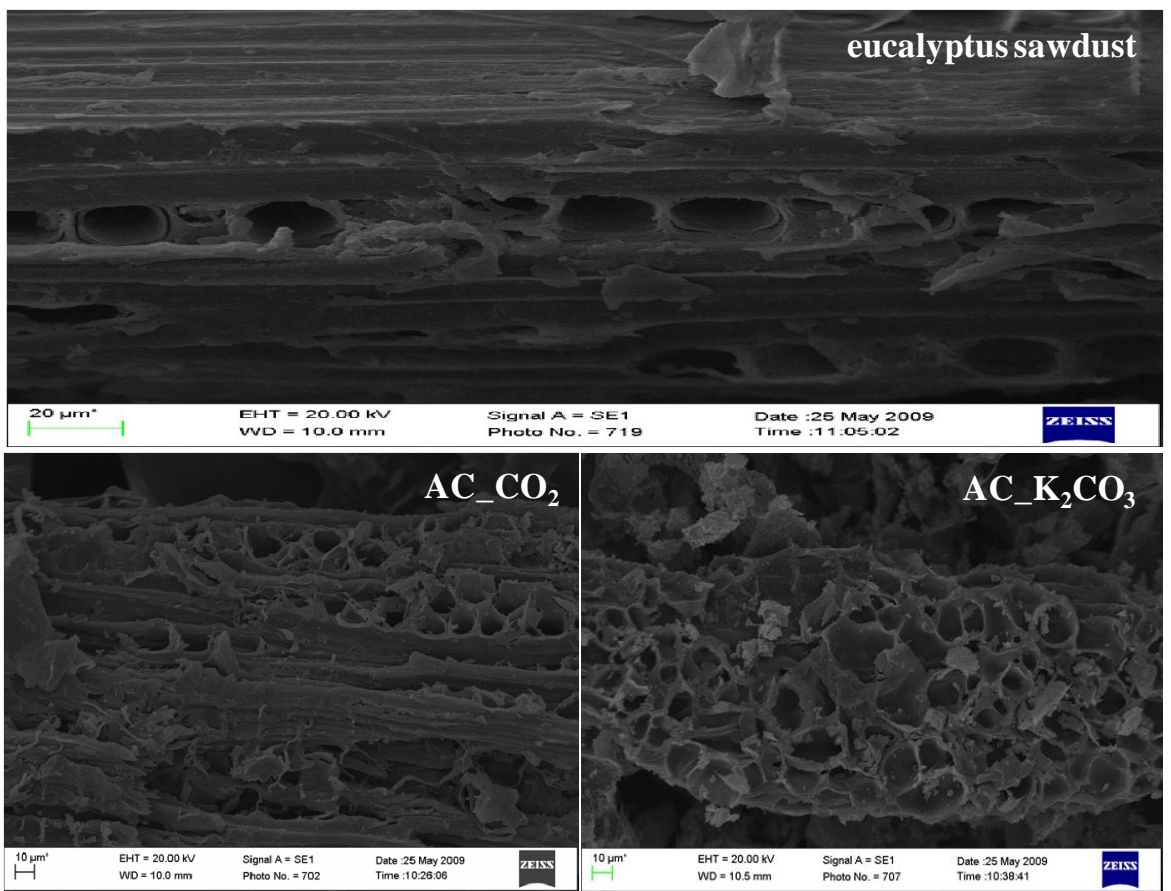

Figure 4 - SEM photographs for eucalyptus sawdust, $\mathrm{AC}_{-} \mathrm{CO}_{2}$ and $\mathrm{AC} \_\mathrm{K}_{2} \mathrm{CO}_{3}$. hydrogen and oxygen decrease. This is because the process of pyrolysis and activation causes a release of volatile compounds, such as water and smaller hydrocarbons.

The physically activated carbon $\left(\mathrm{AC}_{-} \mathrm{CO}_{2}\right)$ has the higher carbon content compared to the chemically activated $\left(\mathrm{AC} \_\mathrm{K}_{2} \mathrm{CO}_{3}\right.$ ).

There is an increase in the $\mathrm{C} / \mathrm{H}$ values when comparing the sawdust and activated carbons, which indicates an increase of the degree of aromaticity after the

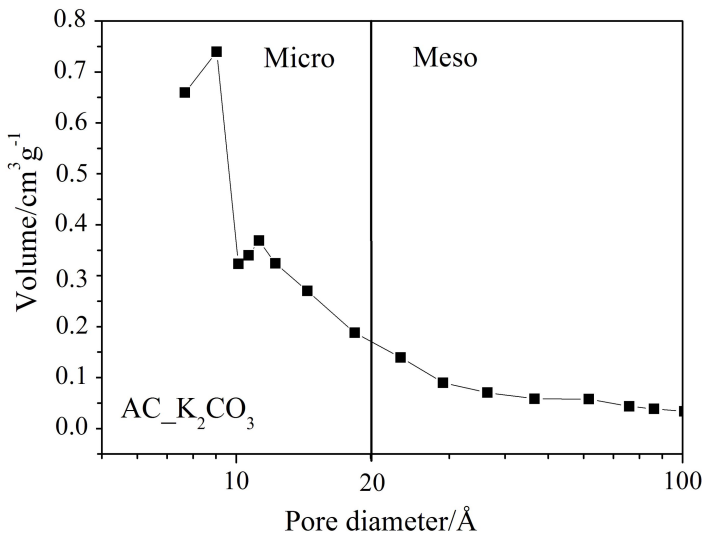


process of pyrolysis and activation. The $\mathrm{C} / \mathrm{H}$ has been accepted as an indication of condensation reactions or flavoring reactions, common in the carbonization and activation process (CHATTOPADHYAYA et al., 2006).

Elementary analysis shows that drastic changes occurred in the material and indicates the efficiency of the process of pyrolysis and activation, since the material produced contains higher amount of fixed carbon and aromatic units.

The FTIR spectrum of sawdust (Figure 5) shows a broad band around $3400 \mathrm{~cm}^{-1}$, corresponding to the axial $\mathrm{OH}$ deformation. It also presents signals at $2930 \mathrm{~cm}^{-1}$, which characterize symmetric and asymmetric vibrations of $-\mathrm{CH}_{2}$ - groups. A band near $1600 \mathrm{~cm}^{-1}$, related to the stretching of lead $\mathrm{C}=\mathrm{C}$ of aromatic groups; a band near the region of $1230 \mathrm{~cm}^{-1}$, related to the vibration of the aromatic lignin ring, and the bands between 1000 and $1050 \mathrm{~cm}^{-1}$, assigned to the stretching of C-O groups of lignin, cellulose or hemicelluloses or C-O-C group of cellulose and hemicelluloses, are also observed.

The infrared spectrum shows some functional groups present in the macromolecular constituents of wood (lignin, cellulose and hemicellulose). The molecules those containing these functional groups are modified during the pyrolysis and activation and, some of these molecules, when in the surface of the material, may make the activated carbons more acidic or alkaline. The spectra of $\mathrm{AC}_{-} \mathrm{CO}_{2}$ and $\mathrm{AC}_{-} \mathrm{K}_{2} \mathrm{CO}_{3}$ are typical for charcoal and the absence of some bands related to functional groups that are present in sawdust, indicate the pyrolysis of the material. In these spectra we can observe a broad band around $3400 \mathrm{~cm}^{-1}(\mathrm{OH})$; a band near $1600 \mathrm{~cm}^{-1}(\mathrm{C}=\mathrm{C}$ of aromatic groups) and a band in the region of $1230 \mathrm{~cm}^{-1}$ (vibration of the aromatic rings).

According to Martins et al. (2007), charcoal from eucalyptus sawdust (pyrolysed at $500^{\circ} \mathrm{C}$ ) presents bands between 3700 and $3600 \mathrm{~cm}^{-1}$, corresponding to free $-\mathrm{OH}$ group, a broad band between 3400 and $3000 \mathrm{~cm}^{-1}$ that can be attributed to the presence of functional groups associated to phenolic $\mathrm{OH}$, alcohols and carboxylic acids. The $1700 \mathrm{~cm}^{-1}$ band features double bonds of $\mathrm{C}=\mathrm{C}$ or $\mathrm{C}=\mathrm{O}$, the $1620 \mathrm{~cm}^{-1}$ band is attributed to aromatic rings and the 1350 and $1450 \mathrm{~cm}^{-1}$ bands correspond to $\mathrm{CH}$ groups.

Table 1 - Elementary analysis of sawdust and activated carbons.

\begin{tabular}{cccccc}
\hline Materials & $\mathrm{C}(\%)$ & $\mathrm{H}(\%)$ & $\mathrm{N}(\%)$ & $\mathrm{O} *(\%)$ & $\mathrm{C} / \mathrm{H}$ \\
\hline Sawdust & 45.5 & 6.2 & 0.13 & 48.1 & 7.34 \\
$\mathrm{AC}_{-} \mathrm{K}_{2} \mathrm{CO}_{3}$ & 80.4 & 2.79 & 0.13 & 16.7 & 28.82 \\
$\mathrm{AC} \_\mathrm{CO}_{2}$ & 89.3 & 1.72 & 0.19 & 8.61 & 51.92 \\
\hline
\end{tabular}

*Calculated from difference.

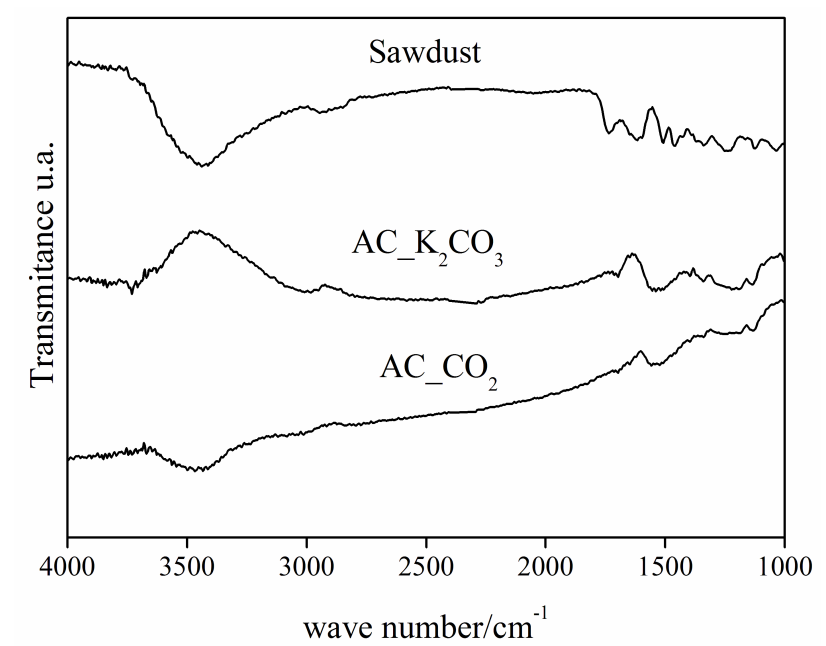

Figure 5 - FTIR spectrum of eucalyptus sawdust, $\mathrm{AC} \_\mathrm{CO}_{2}$ and $\mathrm{AC} \_\mathrm{K}_{2} \mathrm{CO}_{3}$. 
The characteristics of thermal degradation of lignocellulosic materials are strongly influenced by the chemical composition of these materials (cellulose, hemicelluloses and lignin) (ANTAL; VARHEGY, 1995) and the TG curves provide a semi-quantitative understanding of thermal degradation processes that occur during thermochemical conversion (GONZÁLEZet al., 2009). Balci et al. (1993) showed that pyrolysis of wood proceeds by successive degradation of its principal lignocellulosics constituents (hemicelluloses, cellulose and lignin) which vary in thermal behavior. According Wielage et al. (1999) and Gröndahl et al. (2003), hemicelluloses decompose before the cellulose and lignin. García-Ibáñez et al. (2006) identified two areas of pyrolysis: the first, called the active zone, can be attributed to the volatile components generated during the decomposition of cellulose and hemicelluloses and the second, passive area, is due to the conversion of lignin (and part of the cellulose).

The thermogravimetric analysis data of the sawdust and of activated carbons ( $\mathrm{AC} \_\mathrm{CO}_{2}$ and $\mathrm{AC}_{-} \mathrm{K}_{2} \mathrm{CO}_{3}$ ), under nitrogen atmosphere, are shown in Table 2. All materials showed a small weight loss at a temperature close to $100^{\circ} \mathrm{C}$, which can be attributed to water loss.
The thermal degradation of sawdust occurs in two steps. The first weight loss occurs around $240^{\circ} \mathrm{C}$ due to degradation of hemicelluloses and part of cellulose. The second sawdust weight loss occurs at about $350^{\circ} \mathrm{C}$ due to the degradation of remaining cellulose and lignin. The mass stabilization of sawdust occurs at $540^{\circ} \mathrm{C}$ with a weight loss about $40 \%$.

AC_CO ${ }_{2}$ thermal degradation begins at temperatures around $450^{\circ} \mathrm{C}$, stabilizing at $640^{\circ} \mathrm{C}$. The residual mass $\mathrm{CA}_{-} \mathrm{CO}_{2}$ was around $80 \%$.

AC_ $\mathrm{K}_{2} \mathrm{CO}_{3}$ exhibit strong weight loss at temperatures ranging from 300 to $740^{\circ} \mathrm{C}$. The residual mass presented by $\mathrm{AC}_{-} \mathrm{K}_{2} \mathrm{CO}_{3}$ was about $85 \%$.

The activated carbons show higher thermal degradation temperatures than the sawdust, as well as higher thermal stabilization temperatures. $\mathrm{AC}_{-} \mathrm{CO}_{2}$ showed the highest initial thermal degradation temperature $\left(450^{\circ}\right.$ C) while $\mathrm{AC} \_\mathrm{K}_{2} \mathrm{CO}_{3}$ showed the highest thermal stabilization temperatures $\left(740^{\circ} \mathrm{C}\right)$ and highest percentage of residual mass $(85 \%)$. The activated carbons, compared to sawdust, have a higher thermal stability.

Figure 6 shows the adsorption isotherms of methylene blue dye (MB) and phenol using different activated carbons.

Table 2 - Summary of TG degradation temperatures of eucalyptus sawdust, $\mathrm{AC}_{-} \mathrm{CO}_{2}$ and $\mathrm{AC}_{-} \mathrm{K}_{2} \mathrm{CO}_{3}$.

\begin{tabular}{|c|c|c|c|c|c|c|c|}
\hline \multirow{3}{*}{ Materials } & \multicolumn{6}{|c|}{ DT in $\mathrm{N}_{2}\left({ }^{\circ} \mathrm{C}\right)$} & \multirow{2}{*}{$\begin{array}{l}\mathrm{RM} \\
(\%)\end{array}$} \\
\hline & Initial & Final & Initial & Final & Initial & Final & \\
\hline & \multicolumn{2}{|c|}{ Loss of water } & \multicolumn{2}{|c|}{ Degradation } & \multicolumn{2}{|c|}{ Degradation } & \\
\hline Sawdust & 80 & 100 & 240 & 350 & 350 & 540 & 60 \\
\hline AC_CO $\mathrm{CO}_{2}$ & 80 & 100 & 450 & 640 & --- & --- & 80 \\
\hline $\mathrm{AC} \_\mathrm{K}_{2} \mathrm{CO}_{3}$ & 80 & 100 & 350 & 740 & --- & --- & 85 \\
\hline
\end{tabular}

DT $=$ Degradation temperature; $\mathrm{RM}=$ Residual mass at $900^{\circ} \mathrm{C}$
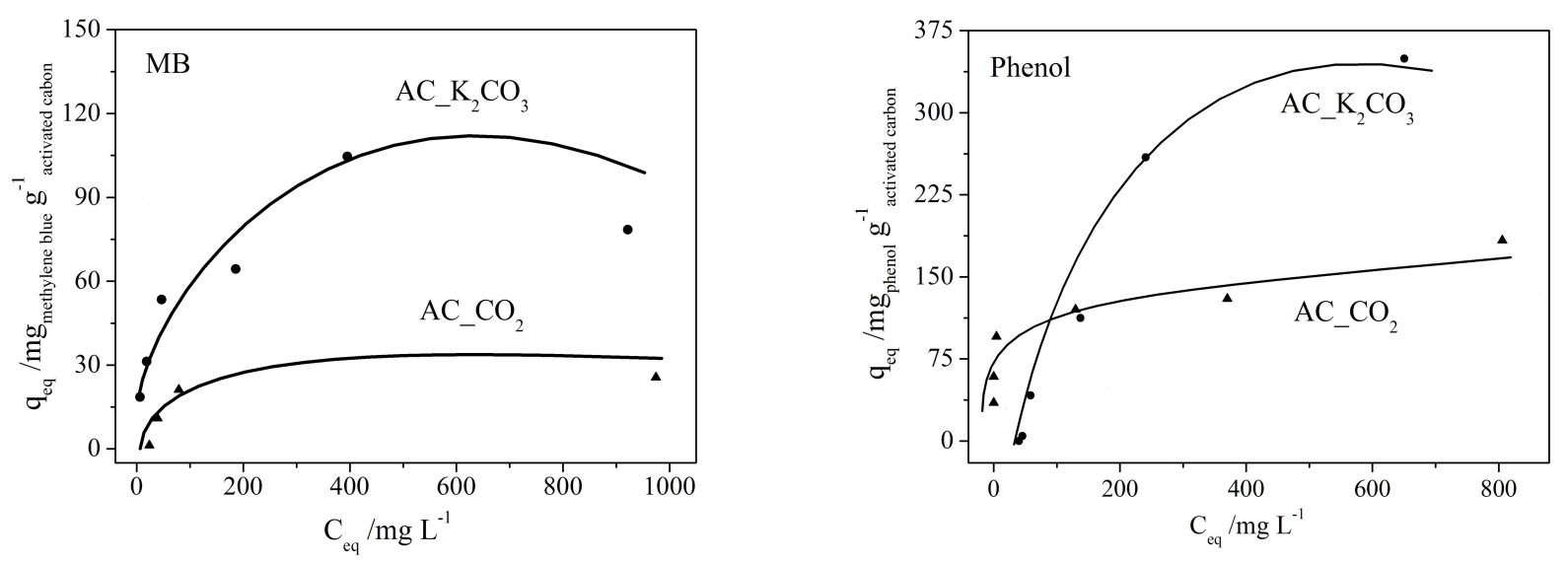

Figure 6 - Methylene blue dye and phenol adsorption isotherms.

Ciênc. agrotec., Lavras, v. 36, n. 1, p. 69-77, jan./fev., 2012 
The experimental results were adjusted according to the models of Langmuir and Freundlich. The best fit for MB was observed for the Langmuir model. The adsorption results are summarized in Table 3. AC_ $\mathrm{K}_{2} \mathrm{CO}_{3}\left(81 \mathrm{mg} \mathrm{g}^{-1}\right)$ was considerably more efficient in the adsorption of MB than $\mathrm{AC}_{-} \mathrm{CO}_{2}(32 \mathrm{mg}$ $\left.\mathrm{g}^{-1}\right)$.
Adsorption of phenol on the different ACs was adjusted according to the Langmuir and Freundlich models. $\mathrm{AC} \_\mathrm{K}_{2} \mathrm{CO}_{3}$ fits better to the Freundlich model and $\mathrm{AC}_{-} \mathrm{CO}_{2}$, to the Langmuir model. The adsorption results of phenol are summarized in Table 4.

AC_ $\mathrm{K}_{2} \mathrm{CO}_{3}$ has a higher adsorption capacity for phenol $\left(330 \mathrm{mg} \mathrm{g}^{-1}\right)$ compared to AC_CO $\mathrm{CO}_{2}\left(172 \mathrm{mg} \mathrm{g}^{-1}\right)$ (Figure 6).

Table 3 - Langmuir parameters for the adsorption of methylene blue on activated carbons.

\begin{tabular}{cccc}
\hline & \multicolumn{2}{c}{ Langmuir parameters } \\
\cline { 2 - 4 } Activated carbons & $\mathrm{q}_{\mathrm{m}}\left(\mathrm{mg} \mathrm{g}^{-1}\right)$ & $\mathrm{K}_{\mathrm{L}}\left(\mathrm{L} \mathrm{mg}^{-1}\right)$ & 0.79 \\
\hline $\mathrm{AC} \_\mathrm{RO}_{2}$ & 32 & 0.004 & 0.99 \\
$\mathrm{AC}_{-} \mathrm{K}_{2} \mathrm{CO}_{3}$ & 81 & 0.034 & 0.9 \\
\hline
\end{tabular}

$\mathrm{q}_{\mathrm{m}}=$ maximum amount of adsorption $\left(\mathrm{mg} \mathrm{g}^{-1}\right) ; \mathrm{K}_{\mathrm{L}}=$ Langmuir constant $\left(\mathrm{L} \mathrm{mg}^{-1}\right) ; \mathrm{R}^{2}=$ coefficient of determination

Table 4 - Freundlich and Langmuir parameters for the adsorption of phenol on activated carbons.

\begin{tabular}{ccccc}
\hline \multirow{2}{*}{ Activated carbons } & \multicolumn{3}{c}{} \\
\cline { 2 - 5 } & Freundlich parameters & $\mathrm{K}_{\mathrm{F}}\left(\mathrm{mg} \mathrm{g}^{-1}\right)\left(\mathrm{L} \mathrm{g}^{-1}\right)^{1 / \mathrm{n}}$ & $\mathrm{n}$ & $\mathrm{R}^{2}$ \\
\hline $\mathrm{AC} \_\mathrm{K}_{2} \mathrm{CO}_{3}$ & Langmuir parameters & 1.26 & 1.11 & 0.92 \\
\hline & & $\mathrm{q}_{\mathrm{m}}\left(\mathrm{mg} \mathrm{g}^{-1}\right)$ & $\mathrm{K}_{\mathrm{L}}\left(\mathrm{L} \mathrm{mg}^{-1}\right)$ & $\mathrm{R}^{2}$ \\
\hline $\mathrm{AC} \_\mathrm{CO}_{2}$ & 172 & 0.071 & 0.96 \\
\hline
\end{tabular}

$\mathrm{K}_{\mathrm{F}}=$ Freundlich constant $\left(\mathrm{mg} \mathrm{g}^{-1}\right)\left(\mathrm{L} \mathrm{g}^{-1}\right)^{1 / n} ; 1 / \mathrm{n}=$ parâmetro de Langmuir; $\mathrm{q}_{\mathrm{m}}=$ maximum amount of adsorption $\left(\mathrm{mg} \mathrm{g}^{-1}\right) ; \mathrm{K}_{\mathrm{L}}=$ Langmuir constant $\left(\mathrm{L} \mathrm{mg}^{-1}\right) ; \mathrm{R}^{2}=$ coefficient of determination 


\section{CONCLUSION}

The activated carbon obtained from the eucalyptus sawdust has certain characteristics such as surface area over $500 \mathrm{~m}^{2} \mathrm{~g}^{-1}$, high microporosity and potential for adsorption of pollutants commonly found in industrial effluents such as phenol and dye. This means that waste of eucalyptus sawdust can be used as precursor in the preparation of activated carbons (AC), using physical $\left(\mathrm{CO}_{2}\right)$ or chemical $\left(\mathrm{K}_{2} \mathrm{CO}_{3}\right)$ activation. The two ACs prepared are microporous with a specific surface area around $535 \mathrm{~m}^{2} \mathrm{~g}^{-1}$ under the preparation conditions. Although $\mathrm{AC} \_\mathrm{CO}_{2}$ and $\mathrm{AC}_{-} \mathrm{K}_{2} \mathrm{CO}_{3}$ have several similarities, they have different adsorption capacities with respect to the tested contaminants (methylene blue and phenol). The $\mathrm{AC}_{-} \mathrm{K}_{2} \mathrm{CO}_{3}$ was most effective in the adsorption of methylene blue $\left(81 \mathrm{mg} \mathrm{g}^{-1}\right)$ and phenol (330 $\mathrm{mg} \mathrm{g}^{-1}$ ).

\section{ACKNOWLEDGEMENTS}

The authors would like to acknowledge CAPES and FAPEMIG for financial support and thank CAPQ-UFLA for the analyses.

\section{REFERENCES}

ANTAL, M.J.; VARHEGY, G. Cellulose pyrolysis kinetics: the current state of knowedge. Industrial \&

Engineering Chemistry Research, Washington, v.34, n.3, p.703-717, feb./mar. 1995.

BALCI, S.; DOGU, T.; YÜCEL, H. Pyrolysis kinetics of lignocellulosic materials. Industrial \& Engineering Chemistry Research, Washington, v.32, n.11, p.25732579, nov./oct. 1993.

BHATNAGAR, A. Removal of bromophenols from water using industrial wastes as low cost adsorbents. Journal of Hazardous Materials, Amsterdam, v.139, n.1, p. 93102, jan./feb. 2007.

CANIZARES, P. et al. Adsorption equilibrium of phenol onto chemically modified activated carbon F400. Journal of Hazardous Materials, Amsterdam, v.131, n.1, p.243248, feb./apr. 2006.

CHATTOPADHYAYA, G. et al. Preparation and characterization of chars and activated carbon from Saskatchewan lignite. Fuel Processing Technology, Amsterdam, v.87, n.11, p. 997-1006, nov./dec. 2006.
CUSTÓDIO, T. N.; BARBIN, D. Modelos de predição para sobrevivência de plantas de Eucalyptus grandis. Ciência e Agrotecnologia, Lavras, v.33, especial, p.19481952, 2009.

DENG, H. et al. Preparation and characterization of activated carbon from cotton stalk by microwave assisted chemical activation - Application in methylene blue adsorption from aqueous solution. Journal of Hazardous Materials, Amsterdam, v.166, n.2, p.15141521, june/july 2009.

DIAS, J.M. et al. Waste materials for activated carbon preparation and its use in aqueous-phase treatment: A review. Journal of Environmental Management, London, v.85, n.4, p.833-846, dec./jan. 2007.

DIN, A.T.M.; HAMEED, B.H.; AHMAD, A.L. Batch adsorption of phenol onto physiochemical-activated coconut Shell. Journal of Hazardous Materials, Amsterdam, v.161, n.2, p.1522-1529, jan./feb. 2009.

DOMINGUES, R.M.A. et al. Eucalyptus globulus biomass residues from pulping industry as a source of high value triterpenic compounds. Industrial Crops and Products, Amsterdam, v.31, n.1, p.65-70, jan./feb. 2010.

DUMAN, G. et al. Production of activated carbon from pine cone and evaluation of its physical, chemical, and adsorption properties. Energy \& Fuels, Washington, v.23, n.4, p.2197-2204, apr./may 2009.

DURAL, M.U. et al. Methylene blue adsorption on activated carbon prepared from Posidonia oceanic (L.) dead leaves: Kinetics and equilibrium studies. Chemical Engineering Journal, Lausanne, v.168, n. 1, p.77-85, mar./ apr. 2011.

GARCÍA-IBAÑEZ, P.; SÁNCHEZ, M.; CABANILLAS, A. Thermogravimetric analysis of olive-oil residue in air atmosphere. Fuel Processing Technology, Amsterdam, v.87, n.2, p.103-107, jan./feb. 2006.

GONÇALVES, M. et al. Produção de carvão a partir de resíduo de erva-mate para a remoção de contaminantes orgânicos de meio aquoso. Ciência e Agrotecnologia, Lavras, v.31, n.5, p.1386-1391, set./ out. 2007. 
GONZÁLEZ, J.F. et al. Pyrolysis of various biomass residues and char utilization for the production of activated carbons. Journal of Analytical and Applied Pyrolysis, Essex, v.85, n.1, p.134-141, may/june, 2009.

GRÖNDAHL, M.; TELEMAN, A.; GATENHOLM, P. Effect of acetylation on the material properties of glucuronoxylan from aspen wood. Carbohydrate Polymers, London, v.52, n.4, p.359-366, june/july 2003.

JUAN, Y.; KE-QIANG, Q. Preparation of activated carbon by chemical activation under vacuum. Environmental Science \& Technology, Washington, v.43, n.2, p.3853390, jan./feb. 2009.

MAHMOODI, N. M.; SALEHI, R.; ARAMI, M. Binary system dye removal from colored textile wastewater using activated carbon: Kinetic and isotherm studies. Desalination, Amsterdam, v.272, n.1-3, p.187-195, may/ june 2011.

\section{MARSH, H.; RODRÍGUEZ-REINOSO, F. Activated}

Carbon. $1^{\text {st }}$ edition, Elsevier Ed., London, 2006.

MARTINS, A.F. et al. Low temperature conversion of rice husks, eucalyptus sawdust and peach stones for the production of carbon-like adsorbent. Bioresource Technology, Essex, v.98, n.5, p.1095-1100, mar./apr. 2007.

NIETO-DELGADO, C.; TERRONES, M.; RANGELMENDEZ, J.R. Development of highly microporous activated carbon from the alcoholic beverage industry organic by-products. Biomass and Bioenergy, Oxford, v.35, n.1, p.103-112, jan./feb. 2011.
OLIVEIRA, L.C.A. et al. Preparation of activated carbons from coffee husks utilizing $\mathrm{FeCl}_{3}$ and $\mathrm{ZnCl}_{2}$ as activating agents. Journal of Hazardous Materials, Amsterdam, v.165, n.1, p.87-94, june/july 2009.

OZKAYA, B. Adsorption and desorption of phenol on activated carbon and a comparison of isotherm models. Journal of Hazardous Materials, Amsterdam, v.129, n.1, p.158-163, jan./feb. 2006.

POLLARD, J. T. et al. Low-cost adsorbents for waste and wastewater treatment: a review. The Science of The Total Environment, Amsterdam, v. 116, n 1-2, p. 31-52, may 1992.

SILVEIRA, R.L.V.A. de.; MOREIRA, A.; HIGASHI, E. N. Crescimento e sobrevivência de mudas de eucalipto sob doses de boro cultivadas em condições de viveiro e de campo. Ciência e Agrotecnologia, Lavras, v.28, n.2, p.366-371, Abr./maio 2004.

SUHAS, P. J. M.; RIBEIRO CARROT, M. M. L. Ligninfrom natural adsorbent to activated carbon: a review. Bioresource Technology, Essex. v.98, n.12,p. 2301-2312, set./out. 2007.

TRUGILHO, P. F. Densidade básica e estimativa de massa seca e de lignina na madeira em espécies de eucalyptus. Ciência e Agrotecnologia, Lavras, v.33, n.5, p.1228-1239, set./out. 2009.

WIELAGE, B. et al. Thermogravimetric and differential scanning calorimetric analysis of natural fibres and polypropylene. Thermochimica Acta, Amsterdam, v.337, n.1, p.169-177, oct./nov. 1999. 